\title{
Pemanfaatan Arang Kulit Kopi Robusta Sebagai Adsorben Penurunan Kadar Amonia Pada Limbah Cair Industri Tahu
}

\author{
${ }^{1}$ Mochammad Ersad, ${ }^{2}$ Lilla Puji Lestari \\ ${ }^{12}$ Fakultas Ilmu Kesehatan Universitas Maarif Hasyim Latif Sidoarjo, Jl. Raya Ngelom Megare No.30, \\ Ngelom, Kec. Taman, Kabupaten Sidoarjo, Indonesia 61257 \\ Correspondence: 1lillapuji@gmail.com \\ Received: 020821 - Revised: 040821 - Accepted: 100921 - Published: 150921
}

\begin{abstract}
Abstrak. Kopi robusta adalah salah satu jenis kopi yang banyak ditanam di Indonesia dengan presentasi $80 \%$ sedangkan $20 \%$ petani menanam jenis kopi arabika. Salah satu limbah yang dapat dimanfaatkan ialah kulit kopi. Kulit kopi robusta mengandung 15-43\% selusosa yang sangat baik digunakan untuk adsorben untuk menurunkan kadar amonia pada limbah cair industri tahu. Limbah tahu banyak mengandung senyawa yang membahayakan bagi lingkungan dan kesehatan. Salah satu kandungan yang berbahaya yaitu amonia. Pada penelitian ini bertujuan untuk mengetahui apakah arang dari kulit kopi robusta dapat menurunkan kadar amonia pada limbah cari indutri tahu, berapa $\mathrm{pH}$ efektif yang digunakan untuk mengurangi kadar amonia serta digunakan untuk mengetahui waktu kontak efisien adsorben dalam mengurangi kandungan amonia pada limbah cair industri tahu. Metode yang digunakan pada penelitian ini yaitu spektrofotometer UV-Vist. Hasil penelitian ini menunjukkan bahwa arang kulit kopi dapat menurunkan kadar amonia dengan pH efektif 9 dan waktu kontak optimum 30 menit.
\end{abstract}

Kata kunci: adsorben, arang kulit kopi robusta, metode spektrofotometer UV-Vist, limbah cair industri tahu.

Citation Format: Ersad. M., Lestari. L.P. (2021). Pemanfaatan Arang Kulit Kopi Robusta Sebagai Adsorben Penurunan Kadar Amonia Pada Limbah Cair Industri Tahu. Prosiding Seminar Nasional Abdimas Ma Chung (SENAM), 2021, 21-29. 


\section{PENDAHULUAN}

Kopi merupakan salah satu industri perkebunan di Indonesia. Terdapat dua jenis kopi yang ditaman di Indonesia yaitu jenis kopi robusta dan jenis kopi arabika. 80\% petani di Indonesia menanam jenis kopi robusta dan $20 \%$ petani menanam kopi jenis arabika.

Kopi robusta telah banyak tersebar di daerah tropis di Indonesia. Kopi robusta dapat tumbuh lebih baik dengan ketinggian 0-1000 mdpl, dimana tempat tersebut tidak cocok untuk menanan kopi jenis arabika. Hal ini yang menyebabkan petani di Indonesia lebih memilih membudidayakan kopi jenis robusta. Salah satu limbah yang dapat dimanfaatkan yaitu kulit kopi, kulit kopi sendiri mempunyai kandungan selulosa 15-43\% dan kaya akan unsur karbon sehingga kulit kopi berpotensi untuk dimanfaatkan sebagai adosorben.

Adsorben merupakan suatu bahan padatan yang dapat menjadi adsorbat. Dimana terjadinya peristiwa menempelnya ion, molekul serta atom pada permukaan. adsorben yang baik digunakan yaitu memiliki daya serap tinggi, zat padat yang memiliki permukaan besar, tidak bereaksi kimia dengan campuran yang akan dimurnikan, tidak beracun, dan dapat digenerasi dengan mudah.

Limbah cair industri tahu merupakan limbah yang berpotensi merusak lingkungan dan mengganggu kesehatan manusia. Dimana limbah industri tahu didapat melalui proses pencucian, perebusan, pengepresan, danpencetahan tahu.

Tabel 1. Karakteristik Limbah Cair Industri Tahu

\begin{tabular}{ccc}
\hline No & Kandungan limbah & Nilai \\
\hline 1 & Padatan terendap & $170-190 \mathrm{mg} / \mathrm{l}$ \\
2 & Padatan tersuspensi & $638-660 \mathrm{mg} / \mathrm{l}$ \\
3 & Padatan total & $668-703 \mathrm{mg} / \mathrm{l}$ \\
4 & Warna & $225-250 \mathrm{pt} \mathrm{Co}$ \\
5 & Kekeruhan & $524-585 \mathrm{FTU}$ \\
6 & Amonia-nitrogen & $23,3-23,5 \mathrm{mg} / \mathrm{l}$ \\
7 & Nitrit-nitrogen & $0,1-0,5 \mathrm{mg} / \mathrm{l}$ \\
8 & Nitrat-nitrogen & $3,4-4,0 \mathrm{mg} / \mathrm{l}$ \\
9 & pH & 10 \\
10 & Bod & $6.000-8000 \mathrm{mg} / \mathrm{l}$ \\
11 & Cod & $7.400-14.000 \mathrm{mg} / \mathrm{l}$ \\
\hline
\end{tabular}




\begin{tabular}{lcc}
\hline & & \\
\hline 12 & Abu & $0,19 \%$ \\
13 & Protein & $0,08 \%$ \\
14 & Karbohidrat & $0,51 \%$ \\
15 & pati & $0,46 \%$ \\
\hline
\end{tabular}

Pada tabel 1 menunjukkan bahwa kadar amonia $\left(\mathrm{NH}_{3}\right)$ pada limbah cair industri tahu cukup tinggi. Apabila kandungan ammonia >35 ppm dapat menyebabkan gangguan kesehatan bagi manusia seperti kerusakan pada ginjal, paru-paru, merduksi pertumbuhan dan malfungsi otak serta penurunan nilai darah (Wahyu Sekar Harjanti, 2016).

Salah satu cara penanganan limbah yaitu dengan mengurangi zat-zat berbahaya seperti amonia yang terdapat pada limbah cair industri tahu. Pengolahan limbah cair industri tahu yang sederhana dengan biaya yang murah, dan efisien dibutuhkan oleh produsen tahu. Salah satu cara yang dapat digunakan ialah pemanfaatan arang kulit kopi robusta sebagai adsorben penurunan kadar amonia pada limbahcair industri tahu.

\section{METODOLOGI PENELITIAN}

Penelitian ini menggunakan metode spektrofotometr UV-Vist. Dilakukan pada tanggal 15 juli 2019 di laboratorium balai penelitian dan konsultasi industri Surabaya. Alat yang digunakan adalah alat gelas laboratorium, ayakan 100 mesh, alat suling, alat pirolisis, spektrofotometer UV-Vist. Bahan yang digunakan adalah limbah cair industri tahu, kulit kopi kering, aquadest, $\mathrm{NaOH} 0,1 \mathrm{~N}, \mathrm{HCl} 0,1 \mathrm{~N}, \mathrm{HCl} 10 \%$, Reagen Nessler.

\section{PROSEDUR PENELITIAN}

\section{Pembuatan Arang Aktif}

Kulit kopi yang sudah kering kemudian dicuci agar terbebas dari kotoran tanah dan pasir. Kulit kopi ditimbang $300 \mathrm{~g}$ dimasukkan ke alat pirolisis (pembakaran tanpa okosigen) pada suhu $400-600^{\circ} \mathrm{C}$ selama 3 jam. Kemudian didinginkan, setelah dingin arang kulit kopi digrinder menjadi partikel-partikel yang lebih kecil yaitu 100 mesh. Kemudian partikel 100 mesh diaktivasi menggunakan $\mathrm{HCl}$ 10\% dipanaskan dengan suhu $120^{\circ} \mathrm{c}$ selama 4 jam. Kemudian dicuci menggunakan aquadest sehingga terbebas dari $\mathrm{HCl}$, keringkan didalam oven pada suhu $100^{\circ} \mathrm{C}$ selama 2-4 jam sehingga diperoleh karbon aktif.

\section{Pengukuran Kurva Standarisasi Amonia}

Penentuan kurva kalibrasi dengan cara menyiapkan larutan standar amonia dengan konsentrasi 1, 2, 3, 4, 5 ppm, pipet masing- masing sebanyak 50ml. Selanjutnya penambahan larutan Nessler $1 \mathrm{ml}$ pada masing- masing konsentrasi, dikocok dan 
didiamkan selama 10 menit. Kemudian mengamati adsorbansi masing-masing pada panjang gelombang 460nm, dan membuat kurvakalibrasi.

\section{Penentuan pH Efisien}

Limbah cair industri tahu diambil sebanyak 100ml dimasukkan kedalam beakerglass kemudian divariasikan dengan $\mathrm{pH} 4,5,6,7,8,9,10$. Pengaturan $\mathrm{pH}$ asam dilakukan dengan penambahan larutan $\mathrm{HCl} 0,1 \mathrm{~N}$ dan pengaturan $\mathrm{pH}$ basa dilakukan dengan penambahan larutan $\mathrm{NaOH} 0,1 \mathrm{~N}$. Setelah $\mathrm{pH}$ diatur, masing-masing ditambahkan 0,5 gram arang aktif, panaskan pada suhu $90^{\circ} \mathrm{C}$ selama 120 menit sambal diaduk. Setelah dingin kemudian disaring untuk mendapatkan filtrate jernih. Filtrate jernih ini yang akan digunakan untuk mengetahui kadar amonia dalam limbah cair industri tahu dengan menggunakan spektrofotometer UV-Vist. Hasil ini yang akan digunakan untuk penelitian selanjutnya.

\section{Penentuan Waktu Kontak Efisien}

Limbah cair industri tahu diambil sebanyak 100ml dengan menggunakan $\mathrm{pH}$ yang sudah ditentukan, dikontakkan dengan $0,5 \mathrm{~g}$ arang aktif, variasikan waktu pengocokan 10, 30, 60, 90, dan 120 menit. Diukur menggunakan spektrofotometer UVVist.

\section{Pengukuran kadar amonia pada limbah cair industri tahu.}

Limbah cair diambil sebanyak 50ml, kemudian masukkan kedalam alat suling, tambahkan $100 \mathrm{ml}$ aquadest maka akan mendapatkan filtrate sebanyak 50ml. kemudian filtrate dipipet 10ml, masukkan kedalam labu ukur 100ml, tambakan pereaksi Nessler $10 \mathrm{ml}$, lalu addkan dengan aquadest sampai tanda batas. Kemudian diukur nilai adsorbsinya menggunakan alat spektrofotometer UV-Vist.

\section{HASIL DAN PEMBAHASAN}

\section{Penentuan Kurva Standarisasi Amonia}

Penentuan kurva kalibrasi dengan cara menyiapkan larutan standar amonia dengan konsentrasi 1, 2, 3, 4, 5 ppm, pipet masing- masing sebanyak 50ml. Kemudian menambahkan larutan Nessler $1 \mathrm{ml}$ pada masing-masing konsentrasi, dikocok dan didiamkan selama 10 menit. Kemudian mengamati adsorbansi masing-masing pada panjang gelombang 460nm, dan membuat kurva kalibrasi seperti tabel 2 dan gambar 1 . 
Tabel 1. Penentuan Adsorbansi

\begin{tabular}{cc}
\hline $\mathbf{N H}_{\mathbf{3}}(\mathbf{p p m})$ & Adsorbansi \\
\hline 0 & 0 \\
1 & 0,1654 \\
2 & 0,3320 \\
3 & 0,4811 \\
4 & 0,6701 \\
5 & 0,8210 \\
\hline
\end{tabular}

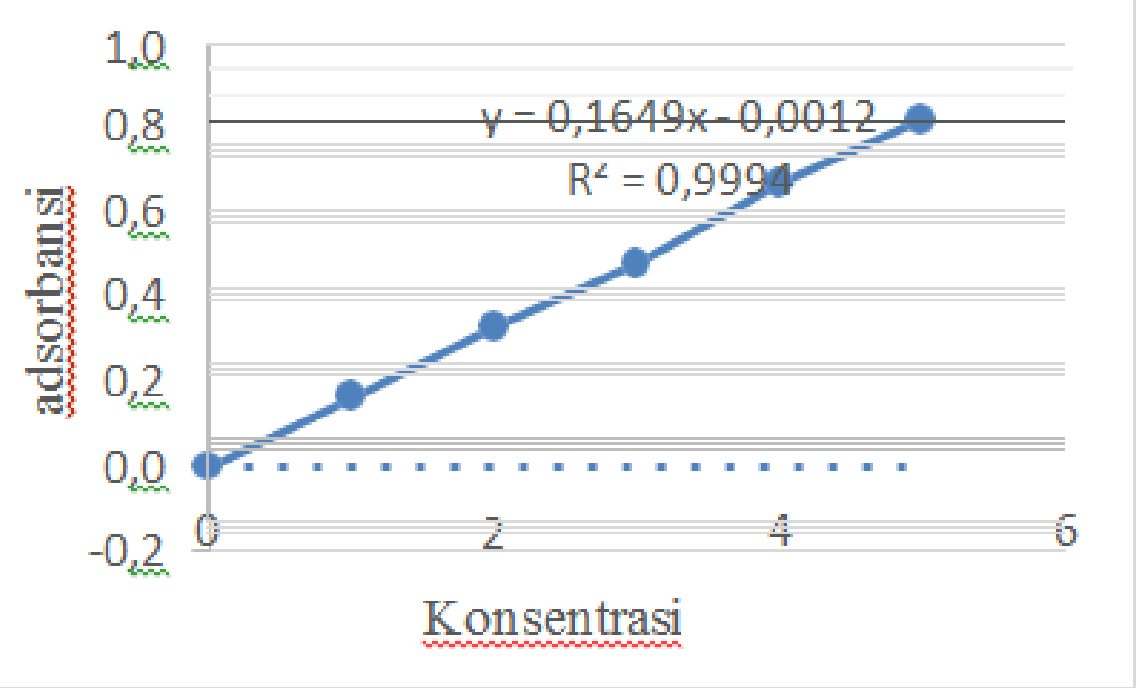

Gambar 1. Grafik Kurva Standarisasi

\section{Penentuan pH efisien dalam menurunkan kadar amonia pada limbah cair industri tahu}

Limbah cair industri tahu diambil sebanyak 100ml dimasukkan kedalam beakerglass kemudian divariasikan dengan $\mathrm{pH} 4,5,6,7,8,9$, 10. Pengaturan $\mathrm{pH}$ asam dilakukan dengan penambahan larutan $\mathrm{HCl} 0,1 \mathrm{~N}$ dan pengaturan $\mathrm{pH}$ basa dilakukan dengan penambahan larutan $\mathrm{NaOH} 0,1 \mathrm{~N}$. Setelah $\mathrm{pH}$ diatur, tambahkan 0,5 gram arang aktif, panaskan pada suhu $90^{\circ} \mathrm{C}$ selama 120 menit sambal diaduk. Setelah dingin kemudian disaring untuk mendapatkan filtrate jernih. Filtrate jernih ini yang akan digunakan untuk mengetahui kadar amonia dalam limbah cair industri tahu dengan menggunakan spektrofotometer UV-Vist. Hasil ini yang akan digunakan untuk penelitian selanjutnya. Data hasil dapat dilihat pada tabel 3 dan grafik 2 
Tabel 3. Hasil Penentuan Nilai pH

\begin{tabular}{ccc}
\hline No & pH sampel & Kadar $\mathbf{N H}_{\mathbf{3}}$ \\
1 & Control & 38,86 \\
2 & 4 & 38,74 \\
3 & 5 & 38,08 \\
4 & 6 & 35,80 \\
5 & 7 & 31,10 \\
6 & 8 & 21,88 \\
7 & 9 & 19,50 \\
8 & 10 & 19,50 \\
\hline
\end{tabular}

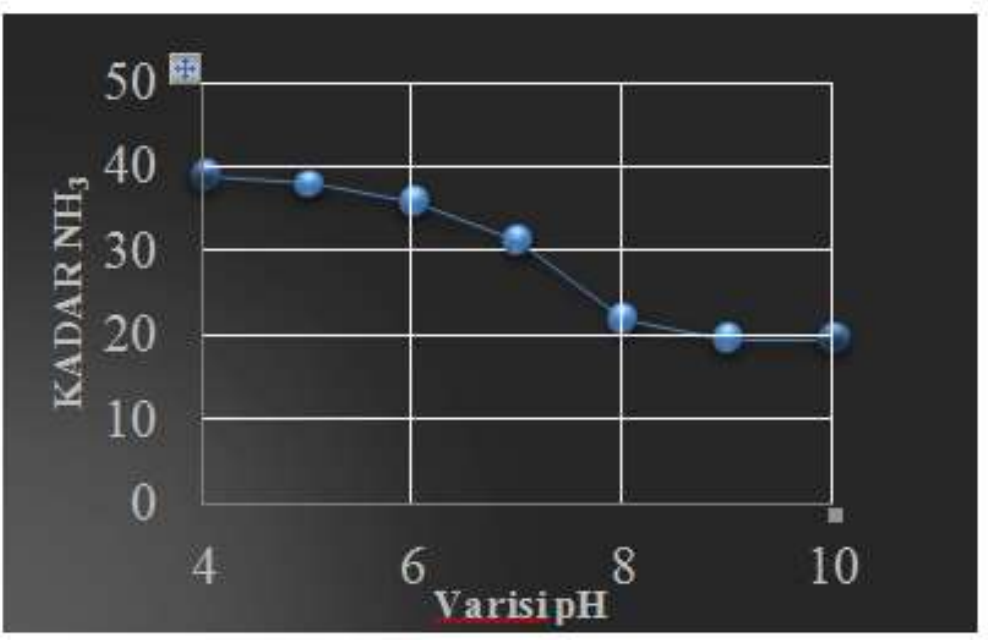

Gambar 2. Grafik pH Efisien

Pada pemeriksaan ini digunakan metode Nessler. Metode ini suatu analisa kimiawi dengan penggunaan alat spektrofotometer. pada percobaan hubungan antara $\mathrm{pH}$ dengan amonia menggunakan adsorban arang aktif kulit kopi terlihat bahwa $\mathrm{pH}$ larutan limbah sangat berpengaruh terhadap daya serap arang aktif kulit kopi. (irmanto dan suyata. 2009)

Dari grafik 2 terlihat bila larutan $\mathrm{pH}$ yang bersifat asam daya serap arang kulit kopi terhadap ammonia rendah atau sisa penyerapan tunggi. Semakin naik $\mathrm{pH}$ larutan daya serap arang aktif kulit kopi terhadap ammonia semakin tinggi atau sisa ammonia dalam limbah cair industri tahu akan semakin kecil. Hal ini disebabkan limbah cair industri tahu suasananya sangat asam $\left(\mathrm{pH}_{4}\right)$ dimungkinkan kandungan ammonia membentuk garam amonium sehingga daya adsorbsinya rendah. Hal ini lah yang membuat pori-pori arang aktuf kulit kopi kurang maksimal dalam menyerap kandungan ammonia pada limbah cair 
industri tahu. Semakin tinggi pH daya serap akan semakin meningkat. Hal ini disebabkan garam ammonium yang terdapat pada limah cair industri tahu akan terurai menjadi ammonia yang akan diserap oleh arang aktif kulit kopi sehingga pada $\mathrm{pH}$ lebih dari 7 sisa ammonia semakin rendah. Pada $\mathrm{pH} 9$ dan $\mathrm{pH} 10$ amonia tersisa tidak berbeda dan paling rendah yaitu 19,50 ppm. Hal ini menunjukkan ammonia tidak berbeda, bahwa arang aktif kulit kopi telah jenuh dan tercapai titik optimal penyerapan pada $\mathrm{pH} 9$.

\section{Penentuan waktu kontak efisien dengan pH yang ditentukan.}

Limbah cair industri tahu diambil sebanyak 100ml dengan menggunakan $\mathrm{pH}$ yang sudah ditentukan, dikontakkan dengan $0,5 \mathrm{~g}$ arang aktif, variasikan waktu pengocokan 10 , 30, 60, 90, dan 120 menit. Diukur menggunakan spektrofotometer UV-Vist. didapatkan data hasil dilihat pada tabel 4 dan gambar 3 .

Tabel 4. Penurunan Kadar NH3

\begin{tabular}{cc}
\hline Waktu & Adsorbansi \\
kontrol & 19,50 \\
$10^{\prime}$ & 13,24 \\
$30^{\prime}$ & 5,88 \\
$60^{\prime}$ & 2,16 \\
$90^{\prime}$ & 0,58 \\
$120^{\prime}$ & 0,54 \\
\hline
\end{tabular}

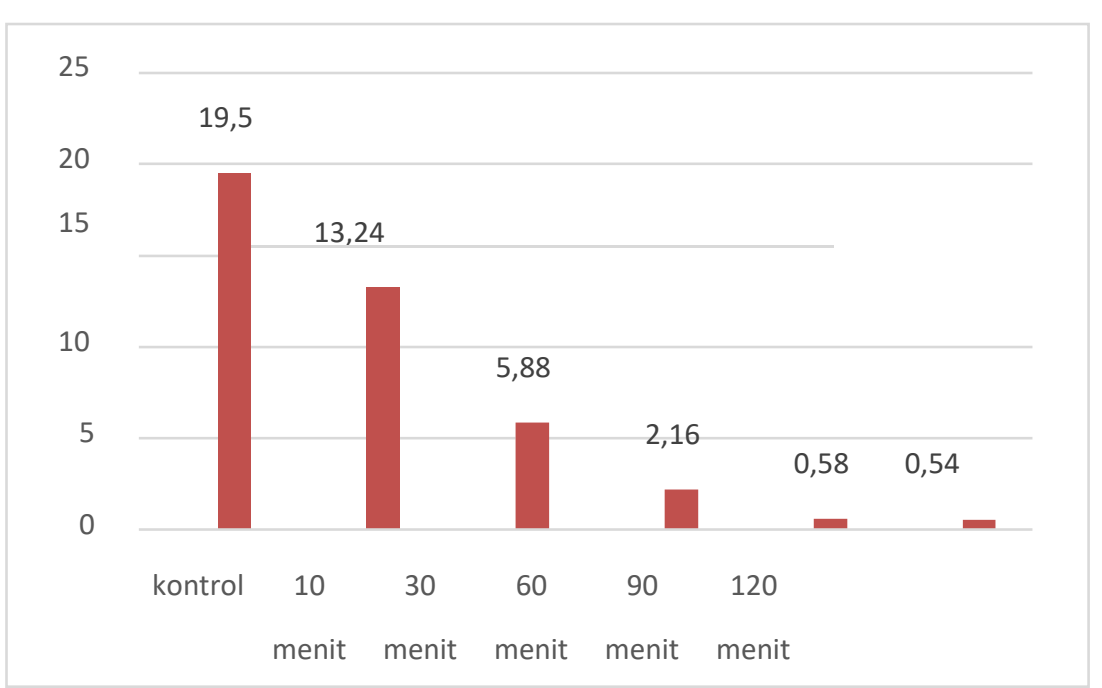

Gambar 3. Grafik penurunan kadar 
Gambar 3 menunjukkan bahwa penyerapan arang aktif dengan ukuran partikel 100 mesh mencapai titik efisien pada waktu kontak 30 menit. Pada waktu 30 menit terjadi penurunan kadar amonia yang signinfikan. Arang yang sudah diaktifasi permukaannya akan menjadi luas karena telah terbebas dari kotoran atau zat-zat yang lain dan pori-porinya telah terubuka sehingga mampu mengadsorbsi amonia (Lubis dan Nasutuion, 2002).

Pada waktu kontak 60 menit terjadi penurunan nilai adsorbsi yang rendah. Hal ini disebabkan arang aktif tidak menyerap dengan maksimal karena pori-pori permukaan telah jenuh atau telah tertutup oleh adsorben. Penurunan nilai adsorpsi terjadi secara terus menerus pada waktu kontak 90 menit dan 120 menit dan terus terjadi penurunan nilai sampai arang aktif kulit kopi mengalami desorpsi yaitu melepaskan kembali zat -zat yang telah diadsorpsi karena arang aktif kulit kopi telah jenuh. Apabila waktu pengocokan diperpanjang, maka arang aktif kulit kopi yang telah menyerap amonia optimum akan dilepas kembali kedalam larutan (limbah cair tahu). Hal ini disebabkan adsorben dari arang aktif kulit kopi mempunyai kapasitas daya serap maksimum dalam menyerap amonia. (irmanto dan suyata. 2009).

\section{KESIMPULAN}

Berdasarkan hasil yang diperoleh dari penelitian pemanfaatan arang kulit kopi robustasebagai adsorben penurunan kadar amonia padalimbah cair industri tahu, maka dapat disimpulkan sebagai berikut :

1. Kulit kopi robusta yang sudah diaktifasi mampu menurunkan kadar amonia pada limbah cair industri tahu.

2. $\mathrm{pH}$ efisien dalam menurunkan kadar amonia pada limbah cair industri tahu menggunakan arang aktif dari kulit kopi robusta dicapai pada $\mathrm{pH} 9$.

3. Waktu kontak efisien dalam menurunkan kadar amonia pada limbah cair industri tahu pada pH 9 dicapaipada waktu kontak 30 menit.

\section{UCAPAN TERIMAKASIH}

Terima kasih kami sampaikan kepada dosen pembimbing serta segenap dosen Fakultas Ilmu Kesehatan UMAHA dan kepada orang tua yang selalu mendukung penelitian ini. 


\section{DAFTAR PUSTAKA}

Harjanri, S.A. 2016. analisis risiko kesehatan lingkungan pajanan gas amonia (NH3) pada pemulung di tpa jatibarang, semarang. 4 (3) 921-930.

Irmanto dan Suyata. 2009. Penurunan kadar amonia, nitrat, dan nitrit limbah cair industri tahu menggunakan arang aktifdari ampas kopi. 4 (2). 105-114.

Lubis, S. dan R. Nasution. 2002. Pemanfaatan limbah bubuk kopi sebagai adsorben pada penurunan kadar besi (Fe anorgamik) dalam air minum, 2. 12-16. 